$\xi=$

\title{
Priorities of Sustainable Building Concept and Evaluation of Possibilities for Energy Efficiency Management of Buildings (As in the Case of Ukraine)
}

\author{
Alina Bohoslovska ${ }^{1}$, Anna Komelina ${ }^{2}$, Svitlana Shcherbinina $^{3 *}$ \\ ${ }^{1}$ Nikolayev National University V.O. Sukhomlynsky, Ukraine \\ 2 PJSC "Poltava-Bank", Ukraine \\ ${ }^{3}$ Poltava National Technical Yuri Kondratyuk University, Ukraine \\ *Corresponding Author E-Mail: Scherbininasveta@Gmail.Com
}

\begin{abstract}
Ensuring the energy efficiency functioning of housing and communal services and increasing the energy efficiency of Ukraine's housing stock, which is one of the largest consumers of heat energy, requires the search for potential opportunities for managing energy efficiency of buildings. Integration into the world economy obliges Ukraine to adhere to international economic principles, one of which is the growth of energy efficiency.

The article examines the experience of the world countries in the field of energy efficiency of buildings on the basis of sustainable building concept. The methodology of calculating the integral rating point of the regions of the country based on their energy saving potential is developed. It can be used to evaluate the potential of energy efficiency management of buildings in Ukraine. As a result of the calculations of the integrated estimation of the energy saving potential, an appropriate ranking and grouping of the regions of Ukraine has been carried out.

Improvement of the organizational and technical potential of providing energy-efficient functioning of the housing and communal services of Ukraine and the introduction of effective mechanisms for its modernization on the basis of the sustainable building concept should ensure an increase in the efficiency of energy efficiency management of buildings.
\end{abstract}

Keywords: Energy efficiency of buildings. Energy saving potential. Housing. Integrated estimation. Sustainable building.

\section{Introduction}

Energy security and energy efficiency in the implementation of the sustainable building concept are considered by the world community as a global challenge of the 21 st century. The developed countries of the world, in particular the EU, whose experience deserves attention, have already made significant progress in addressing energy efficiency issues, they continue seeking new energy sources and develop energy efficiency measures. The economic model of Ukraine's development is characterized by an extremely high level of energy consumption, dependence on energy produced outside its borders, by the lack of influence on the formation of the price level for imported energy resources, first of all for natural gas, by the inability to substantially diversify the geography of its supply. Considerable factors of increasing energy efficiency should be attributed to the fact that Ukraine, being integrated into the world economy, is obliged to adhere to international economic principles, one of which is the growth of energy efficiency.

More than $30 \%$ of the total fuel consumption in the overall structure of energy costs in Ukraine accrue to the housing and municipal sector; it is one of the largest consumers of thermal energy. At the same time, the rapid growth of energy prices for consumers (for 2013-2017 for natural gas more than 5 times, for electricity more than 3 times, for heat energy - almost 4 times), high level of depreciation and obsolescence of thermal and electric networks, equipment and buildings are taking place against the background of lowering the level and quality of life of the population and increasing the burden on the state budget of the country through the provision of subsidies for almost 9 million households. Nevertheless, in Ukraine there is an organizational and technological potential of energy saving and energy efficiency improvement of the housing stock. The country's energy poverty is to some extent due to the inefficient use of available resources. The current situation poses the issue of saving energy resources in one line with the key issues of the country's economic security, and the introduction of energy saving measures at all levels of the economic mechanism is a priority task, the solution of which depends on the functioning and even survival of the entire country.

From this perspective, the search for potential energy efficiency of buildings in Ukraine requires the study of world experience in this area, the identification of the existing organizational and technical capacity to ensure energy efficient functioning of the housing and communal services of Ukraine and the introduction of effective mechanisms for its modernization based on the concept of Sustainable building.

\section{An Overview of Recent Research Sources and Publications}

Problems of energy efficiency of buildings are actively investigated by scientists from all over the world. The issue of using energy- 
efficient measures in residential buildings in the United States and determining their impact on the cost of housing is presented in Im J., Seo Y., Cetin K.S., Singh J. (2017) [1]. The economic efficiency of investment in energy efficiency in the affordable housing market in the Netherlands is determined by Chegut A., Eichholtz P., Holtermans R. (2016) [2]. The study of the results of the analysis of thermal and energy indicators of social housing projects in Brazil, taking into account climate change and the effect of introducing energy efficiency measures in this sector, has been carried out by Triana M.A., Lamberts R., Sassi P. (2018) [3]. The challenges of modernizing social housing in Mexico to improve energy efficiency and thermal comfort are described by MedranoGomez L.E., Izquierdo A.E. (2017) [4]. The analysis of demand for low carbon residential buildings from the standpoint of households and building campaign specialists was studied by Romanach L., Leviston Z., Jeanneret T., Gardner J. (2017) [5]. Methods of support of households in Australia to decide on the reconstruction of an existing housing stock to the level of houses close to zero energy consumption, an evaluation of possible solutions that can be implemented over time, the implementation of selected solutions and the measurement of the impact of these solutions in terms of net energy balance, demand, comfort and cost are reviewed by Miller W., Liu L.A., Amin Z., Gray M. (2018) [6]. An overview of existing NZEB projects, the formulation of NZEB development strategies for Australia and the identification of potential NZEB research areas is described by Wells L., Rismanchi B., Aye L. (2018) [7]. The method for assessing energy poverty in low-income households, which includes the climatic, construction and socio-economic features of Spain, is illustrated by Sanchez-Guevara Sanchez C., Neila Gonzalez F.J., Hernandez Aja A. (2018) [8]. The use of the hedonic pricing method to determine the price of energy efficiency in the Spanish housing market is presented by De Ayala A., Galarraga I., Spadaro J.V. (2016) [9]. The issue of using renewable energy in the context of social housing, namely, the factors of success, barriers and motivation, is considered by Annie McCade, Pojani D., Groenou A.B. (2018) [10]. Femenias P., Mjornell K. Thuvander L. (2018) investigated the concept of renovation of the housing stock in Sweden in relation to the European energy policy and proposed directions for its partial reconstruction, which can combine energy efficiency with the environmental, financial, social and cultural objectives of housing management [11]. The trends of energy efficiency in the Dutch non-commercial housing sector are analyzed in the paper by Filippidou F., Nieboer N., Visscher H. (2017) [12]. The use of nonlinear methodology and an interdisciplinary approach to household energy consumption, in particular the analysis of the covariance structure, to isolate the direct and indirect effects of household and housing characteristics for total annual domestic energy consumption has been investigated by Estiri H. (2015) [13]. The questions of green building, the quantitative assessment of the benefits of green buildings compared to conventional buildings and different approaches to the achievement of green buildings is considered by Zuo J., Zhao Z.-Y. (2014) [14]. The problems of energy efficiency in Malaysia, in particular through energy efficiency measures in the construction sector, since energy efficiency in buildings is crucial for reducing energy use and improving local environmental sustainability, has been studied by Shaikh P.H., Nor N.B.M., Sahito A.A., Nallagownden P., Elamvazuthi I., Shaikh M.S. (2017) [15]. An evaluation of the impact of municipal construction bodies and their potential actions in the area of energy efficient and sustainable construction and repair is investigated by Hakkinen T., Rekola M., Ala-Juusela M., Ruuska A. (2016) [16]. The study of the difference in energy efficiency depending on the consumer group and its type was reflected in the work of Gillingham K., Palmer K. (2014) [17]. The analysis of global energy use, utility incentives and tariffs, as well as energy management programs for buildings, is presented by Smith G., Parmenter K. (2015) [18]. The potential of the utility market, the role and tasks of its players, the modeling of demand and forecasting energy prices are studied by Sioshansi F.P. (2016) [19]. Energy efficiency management strategies for the efficient use of resources under conditions of technological progress are given in the works of Kayakutu G., Mercier-Laurent E. (2016) [20]. Problems of energy saving in the housing stock were considered by Ukrainian scientists: V.O. Kapustian, M.G. Chepeliev (2014) that proposed an approach to study the adequacy of economic and mathematical tools used to assess the effects of subsidies in the energy sector of the economy or housing and communal [21]. The technical condition of the housing stock of Ukraine was investigated by M.K. Sukhonos, T.G. Molodchenko (2014) [22]; problems of energy saving in a housing stock by V.P. Volkov (2013) [23]. The program of activation of investment processes in alternative energy, and also the expected benefits from its implementation are considered and has been proposed by V. Onyshchenko, S. Sivitska (2014) [24].

As the interest in research on energy efficiency in residential buildings is increasing, this article is an attempt to analyze the experience of the countries of the world in this area, which is relevant for Ukraine.

\section{Purpose of the Article}

The main objective of this work is to determine the priorities of the concept of Sustainable building and to develop a methodology for calculating the integral rating point of the regions of the country for their energy conservation potential, which can be used to evaluate potential energy efficiency of buildings in Ukraine.

\section{The Effectiveness of Energy Efficiency Management in the World}

In the world for the period of 1990-2016, due to the introduction of energy-efficient technologies, the positive dynamics of reducing the energy intensity of world GDP by $31.5 \%$ was observed, while maintaining annual growth in total energy consumption (20\%) and energy consumption per capita was almost unchanged [25]. At the same time, the volume of world GDP for 2000-2016 grew by $77 \%$.

According to the Enerdata statistics for 2000-2016, the energy intensity of the GDP fell by $27,1 \%$ in the US, by $25,5 \%$ in the EU as a whole, including $39,3 \%$ in the UK, by 22 in Germany, $3 \%$ with corresponding growth of GDP (by $33 \%, 25 \%, 32 \%, 21 \%$ ). In China, during this period, GDP grew by 3.25 times, with a $35 \%$ reduction in energy intensity. The energy intensity of GDP in Ukraine in this period has been reduced by $48.3 \%$, with GDP growth by $39 \%$, however, this figure in Ukraine remains one of the highest in the world, (Figure 1).

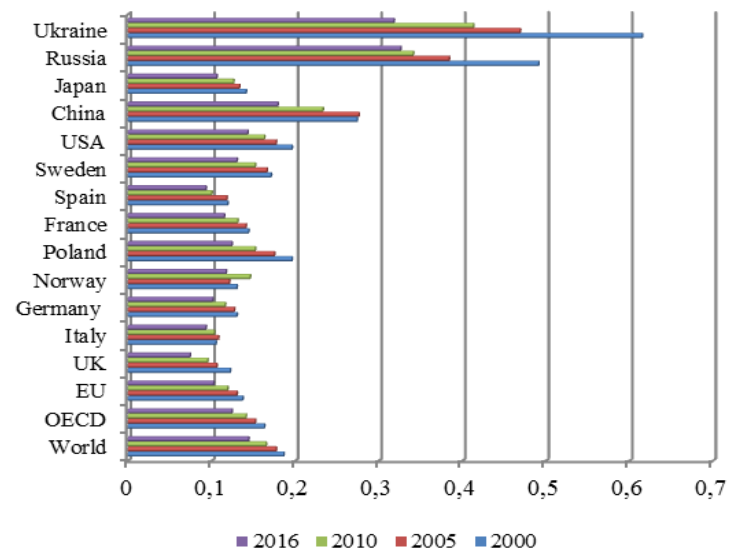

Fig. 1: Dynamics of energy intensity of world GDP for 2000 - 2016 [25]

In 2016, global investments in energy efficiency in the energy sector amounted to $\$ 231$ billion. The United States increased by 9\% [26]. The highest investment growth rates in energy efficiency were in China - 24\%. The largest share of global energy efficiency investments in energy is accumulated in Europe. Among sectors of the economy, investment in energy efficiency is dominated by the 
construction sector - 58\% (\$133 billion) of world investment in 2016, with most investments in this sector being directed towards heating / air conditioning and lighting (Figure 2).

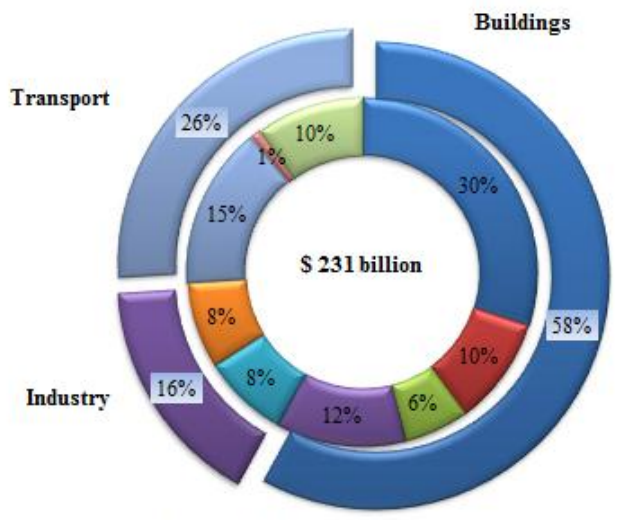

a Thermal insulation of buildings

aHeating, ventilation, air conditioning and controls

$\square$ Devices

aLighting

Energy-intensive industry

$\square$ Other industries

$₫$ Premium payments for the use of energy efficient vehicles

uSubsidization of electric transport

$\checkmark$ Freight vehicles

Fig. 2: The structure of investments in energy efficiency in the world and the main directions of investment, 2016 [26]

Advances in energy efficiency provide total energy savings of $\$ 540$ billion mainly in the "building" and "industry" segments. International experience shows that, in the absence of coordinated national policies and the development of an effective model for managing these processes at national, regional, local level, energy efficiency measures do not bring significant results.

\section{Principles of Implementation of Sustainable Building Concept and Priorities of Energy Efficiency Management of Buildings}

Energy conservation in construction is closely linked to the concept of sustainable building and the concept of sustainable development. The key task of energy efficiency of the building is to apply the project approach to energy efficiency management throughout its life cycle (from planning to designing, construction, exploitation, maintenance, reconstruction, and demolition), which creates conditions for the quality of the environment, efficient use of resources such as energy, water and materials. The implementation of the model of sustainable development for building envelope requires compliance with four basic principles: environmental protection, justice, public participation and the future (Figure 3) [28].

The model of sustainable development for building is based on the principles of sustainable development, which requires balance of all the factors of sustainability - economic, energy, environmental and social. One of the priorities of the sustainable building concept is the energy efficiency of buildings, which requires energy audit and energy management for energy efficiency of buildings. To this end, it is expedient to use the experience of the EU countries in classifying buildings by the criterion of low energy consumption (Figure 4) [29]:

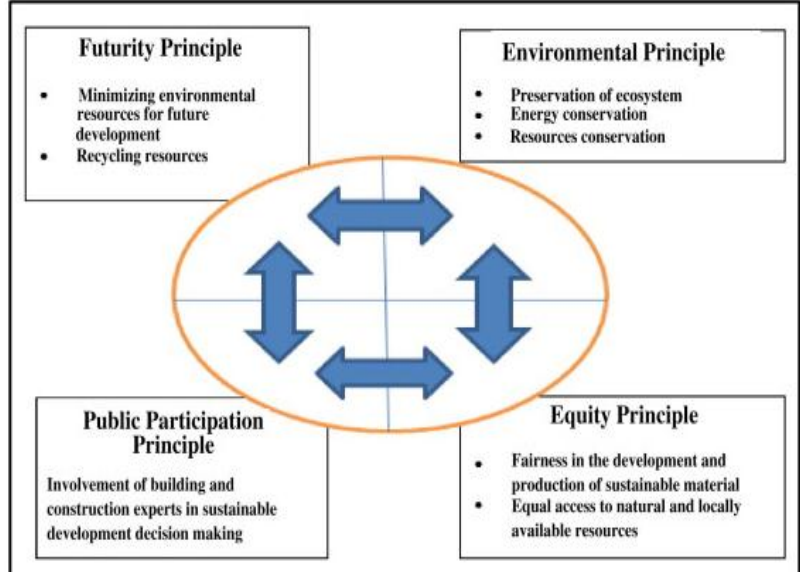

Fig. 3: Modified model of sustainable development for building envelope

1. Energy Efficiency Building - a building in which energy efficiency is achieved through the use of innovative solutions that can be implemented technically, economically justified, and taken ecologically and socially, and do not change the normal way of life.

2. Low energy buildings - buildings which constructed by using modern building materials, in which the annual specific energy consumption for heating is from 50 to $80 \mathrm{kWh} / \mathrm{m} 2$.

3. Zero energy buildings - buildings with high energy efficiency, able to produce energy from renewable sources on site, and consume it in equal quantities during the year.

4. Passive buildings - buildings that provide special measures for the use of non-traditional (renewable) energy sources and have a significant impact on reducing energy consumption from traditional sources.

5. Smart buildings - automated buildings, organized for the convenience of people living with high-tech devices.

6. Intelligent buildings - buildings in which the processes of heat supply and climate control, determined on the basis of the use of computer technology, optimized heat and mass flows in the premises and fencing structures.

7. High-tech buildings - buildings in which energy savings, microclimate quality and environmental safety are achieved through the use of know-how-based technical solutions.

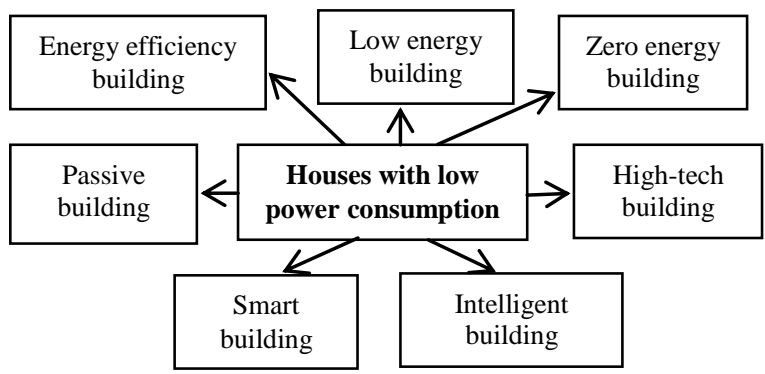

Fig. 4: Classification of houses with low power consumption

Heat-energy characteristics of low-rise buildings of various degrees of energy efficiency as in the case of Germany are shown in Table 1.

Table 1: Heat energy costs by type of buildings in Germany [31]

\begin{tabular}{|l|c|c|}
\hline $\begin{array}{c}\text { Individual residential house } 140 \\
\mathrm{~m}^{2} \text { of total area }\end{array}$ & $\begin{array}{c}\text { Annual expenditure } \\
\text { of heat } \mathrm{kWh} / \mathrm{m}^{3} \text { per } \\
\text { year }\end{array}$ & $\begin{array}{c}\text { Specific heat } \\
\text { consumption } \\
\mathrm{Wh} / \mathrm{m}^{2}\end{array}$ \\
\hline The old building & 300 & 136 \\
\hline $\begin{array}{l}\text { A typical house of the 70's of the } \\
\text { twentieth century }\end{array}$ & 200 & 91 \\
\hline $\begin{array}{l}\text { A typical home of the 80's of the } \\
\text { twentieth century }\end{array}$ & 150 & 68 \\
\hline $\begin{array}{l}\text { Low energy building of the 90's } \\
\text { of the twentieth century }\end{array}$ & $0-70$ & $14-32$ \\
\hline House of ultralow power con- & $30-15$ & \\
\hline
\end{tabular}




\begin{tabular}{|l|l|l|}
\hline sumption & & \\
\hline Modern passive house & less than 15 & less than 7 \\
\hline
\end{tabular}

For comparison, the heat and power characteristics of low-rise buildings of various degrees of energy efficiency in Ukraine are given taking into account existing building standards (State Building Standarts), (Table 2).

Table 2: Heat energy costs by type of buildings in Ukraine [32]

\begin{tabular}{|l|c|c|}
\hline \multicolumn{1}{|c|}{$\begin{array}{c}\text { Individual residential house } \\
140 \mathrm{~m}^{2} \text { of total area }\end{array}$} & $\begin{array}{c}\text { Annual expenditure } \\
\text { of heat } \mathrm{kWh} / \mathrm{m}^{3} \text { per } \\
\text { year }\end{array}$ & $\begin{array}{c}\text { Specific heat } \\
\text { consumption } \\
\mathrm{Wh} / \mathrm{m}^{2}\end{array}$ \\
\hline $\begin{array}{l}\text { Old buildings (until the mid } \\
\text { 90's of the twentieth century) }\end{array}$ & 600 & 125 \\
\hline $\begin{array}{l}\text { Buildings according to SBS } \\
\text { 2.2-15-2005 }\end{array}$ & 150 & 70 \\
\hline Low energy buildings power & $30-15$ & $14-32$ \\
\hline $\begin{array}{l}\text { House of ultralow } \\
\text { consumption }\end{array}$ & less than 15 & less than 7 \\
\hline Modern passive house
\end{tabular}

The above-mentioned heat and power characteristics of residential buildings show that typical houses of the 80's of the twentieth century in Germany correspond to for their characteristics for buildings built in Ukraine according to STS 2.2.-15-2005, and old buildings in Ukraine exceed twice annual heat costs compared to old buildings in Germany.

The norms of maximum heat expenditures accepted in Ukraine correspond to European norms, which fluctuate at the level of 30$40 \mathrm{kWh} / \mathrm{sq}$. m. At the same time, the actual energy consumption of most residential buildings in our country is at the level of 150-250 kWh/sq. m. [30]. In EU Member States, building energy efficiency standards are gradually being increased and accompanied by monitoring requirements with appropriate penalties for noncompliance [29].

Another priority of the Sustainable building concept in Ukraine is the widespread introduction of new technologies for the construction of energy-efficient residential, utility buildings and premises This is in line with the Law of Ukraine "On Priority Areas of Innovation Activity in Ukraine" (2012), where the first strategic priority direction of innovation activity for 2011-2021 is the development of new technologies for energy transportation, implementation of energy-efficient, resource-saving technologies, development of alternative energy sources. Ensuring energy saving in housing construction is a hard and complex task and involves the simultaneous solution of tasks: 1) increasing energy efficiency of residential buildings; 2) increasing of energy efficiency of construction; 3) increasing of energy efficiency of building materials. Therefore, the general (integrated) energy efficiency indicator of the building is derived from the chosen methods and methods of solving this complex task. Such indicator serves as a general (integral) indicator of energy efficiency of the building (shows the ratio between total energy consumption per year and total building area).

It is necessary to clearly define the criteria for assessing the effectiveness of energy efficiency management of buildings in the context of the Sustainable building concept, taking into account the real state of housing and communal services, which should form the basis for identifying priority measures in this area. For example, it is not necessarily a home should use less energy, but it should reduce energy that flow from external thermal and electric networks by increasing heat insulation, recovery; own production (using solar panels, collectors, heat pumps, wind turbines) and direct solar heating.

In Austria, Germany, Belgium, Greece and Spain, energy efficiency calculations for buildings should only be performed by the experts who have the appropriate license. In Denmark, Portugal, Sweden and Ireland, the results of calculations are presented in the form of annual consumption of the building of final energy; in Germany, France, Holland, Greece - in the form of annual consumption of primary energy; in Spain and in Finland - in the form of heat transfer coefficient of individual elements of the building enclosing structure; in Norway, the results of calculations are presented as energy consumption and heat transfer coefficients.
The construction of passive and green buildings that fully cover environmental problems is today's main trend in Europe and in the world. These technologies set goals such as: reducing the harmful effects of construction activities on human health and the environment, which is achieved through the use of new technologies and approaches; creation of new industrial products; reducing the load on regional energy networks and increasing the reliability of their work; efficient use of energy, water and other resources; reduction of waste, emissions and other environmental impacts. The first passive house was built in Darmstadt (Germany) in 1991 It is the result of scientific research by scientist Wolfgang Fiesta. Physics-builder calculated the energy balances of buildings until he failed to calculate such indicators of the building, when application of a special heating system would not be needed at all. The energy concept of "passive house" allows to reduce energy consumption in new buildings by $8-10$ times. While conventional buildings in Germany consume from 150 to $250 \mathrm{~kW} / \mathrm{m}^{2}$ per year, a "passive house" only has $10-15 \mathrm{~kW} / \mathrm{m}^{2}$ per year [33].

In 1998, the first such house was built in Austria. Subsequently, passive houses appeared in Germany, Switzerland, France, Austria In 2010, 25,000 homes were already built in Poland, the Czech Republic, Hungary, Slovakia and Russia. More and more new buildings are being certified at the Passive House Institute in Darmstadt. The certificate provides greater prestige and, consequently, the cost of the building.

Building a passive house is more difficult than usual, given that the design stage requires increased impact on all details. For example, to reduce heat loss it is not enough just to take as thick a heater and cover them with the outer surface of the building. It is necessary to eliminate the so-called bridges of heat. Bridges of heat - these are the places in which as a result of violation of the continuity of the thermal insulation shell, heat output is increased. In other words, where different building materials with different thermal conductivity are joining (with each other), where noninsulated parts are included in isolated areas, and so on. The heat bridge can lead to condensation, moisture, growth of fungi, and finally - to the heat loss of the premises, namely: ventilation and roof - 35\%; windows and doors - 25\%; other designs - 40\% (Figure 5).

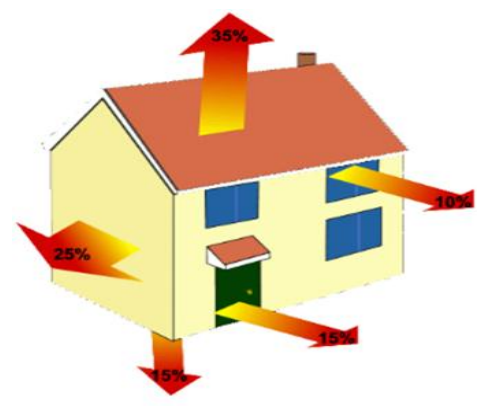

Fig.5: Structure of house heat losses

Conditions for designing and building the thermal balance of the building are determined by the orientation of the building, the presence of windows, their size and location, lighting facilities, air conditioning systems, ventilation and heating, the use of solar and geothermal energy.

To compare heat loss, a thermogram of "ordinary" buildings and passive ones is presented (Figures 6 - 7) [32].

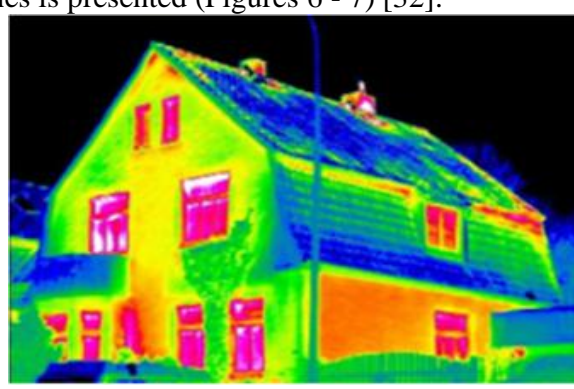

Fig. 6: Heat loss of the "ordinary" house 


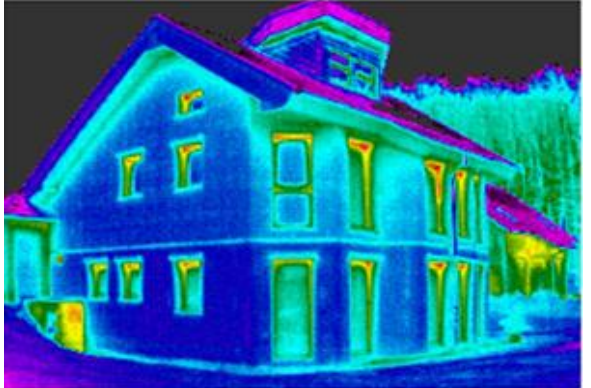

Fig. 7: Heat loss of the passive house

The heat loss of a passive house is close to zero. Under the same conditions, an ordinary house "heats" the street. The passive house is approximately $15-20 \%$ more expensive than the "ordinary" residential building, with the operating costs of heating less than $80 \%$, which allows to recover initial costs quickly [32].

It should be noted that along with the construction of residential low-rise passive houses, energy-saving technologies have become widely used in regular urban development. The main task of the target state programs of European countries was the bringing of all objects of development to the conditionally passive level (houses of ultralow consumption - up to $30 \mathrm{kWh} / \mathrm{m} 3$ per year).

In Germany, as a result of the implementation of the housing rehabilitation program, until now, virtually there is no "ineffective" buildings have been left, and since 2002 all new buildings have to be houses with low energy consumption. Such a house for one family spends no more heating than $90 \mathrm{kWh} / \mathrm{m} 3$ per year, and even it can dispense with heating (taking into account the relatively mild climate).

Consequently, the massive construction of semi-passive houses in Europe becomes a reality. Primary costs for high-tech materials, automation systems and energy consumption control systems will pay off during the first years of operation of such buildings and will allow to save a lot of money. Therefore, pragmatic Europeans consider increasing the energy efficiency of their houses as a longterm and profitable investment.

As for green houses, the technology of their construction is diverse and has many advantages (ecological, economic, energysaving). They can be classified in 5 varieties: mainstream, that relies on the saving of heat and water, often used systems for collecting rainwater; ecohightech - most often office buildings with complex engineering systems, complex facades, garbage recycling systems, etc.; autonomous ecotourism is the autonomy and independence of buildings and settlements from external sources of energy; ecolowtech - a return to the past with a rate on natural local materials (wood, clay, straw, reeds) [34].

Technology of a passive house in Ukraine began to be used about 10 years ago, while in Europe it has been used for almost 35 years. The main obstacle to the spread of this technology is the high initial costs, low awareness of this concept among construction industry and population. In Ukraine, the first passive house was built in 2008 by architect Tatiana Ernst (so-called "Sunshine Home"), which was introduced into the database of the Institute of Passive House in Darmstadt [33].

Measures to improve energy efficiency, carried out by countries, differ in composition and content in accordance with the state of their socio-economic development and the priority of the rational use of energy resources in the state economic policy.

\section{Evaluation of the Organizational and Tech- nical Potential of Ensuring Energy Efficient Functioning of the Housing and Communal Services of Ukraine in a Regional Context.}

Evaluation of the potential of energy saving in the housing and communal services of Ukraine provides the basis for determining the introduction of effective mechanisms for its modernization based on the concept of Sustainable building and the priority measures in this area. The GDP energy intensity is one of the main indicators for evaluation of the efficiency of energy use in the country. At the same time, when comparing the energy efficiency of different countries and regions of the world, the structure of the economy is not taken into account. For example, in the energy consumption of Ukrainian industry, metallurgy accounts for $60 \%$, and on average in the EU - 20\%. The energy intensity of the Ukrainian economy, excluding purchasing power parity (PPP), is exceed ten times the average for OECD countries and exceed three times based on PPPs. At the same time, the energy intensity adjusted for the structure of the economy in Ukraine is only 1.7 times higher than the average for the EU [35].

An effective energy efficiency policy should start with identifying potential energy efficiency management, its organizational and technical components. The housing stock of Ukraine built in Soviet times, is not primarily intended for energy-efficient energy consumption. Therefore, taking into account the technical condition and the number of housing stock, private and multi-apartment buildings, which require significant investments, are a priority area of energy modernization (Table 3 ).

Table 3: Evaluation of investment needs for energy modernization of buildings [36]

\begin{tabular}{|c|c|c|c|}
\hline ]Dimension & $\begin{array}{l}\text { Investment } \\
\text { need }\end{array}$ & $\begin{array}{l}\text { Potential for } \\
\text { reducing gas } \\
\text { consumption }\end{array}$ & $\begin{array}{c}\text { Reducing } \\
\text { consumption } \\
\text { of } \$ 1 \text { billion } \\
\text { investment }\end{array}$ \\
\hline $\begin{array}{l}\text { Reconstruction of } \\
\text { multi-apartment } \\
\text { buildings }\end{array}$ & $\$ 17$ bn. & $\$ 2,3$ bn. $\mathrm{m}^{3}$ & $135 \mathrm{~m} \cdot \mathrm{m}^{3}$ \\
\hline $\begin{array}{l}\text { Reconstruction of } \\
\text { individual houses }\end{array}$ & $\$ 28$ bn. & $\$ 4,7$ bn. $\mathrm{m}^{3}$ & $168 \mathrm{~m} \cdot \mathrm{m}^{3}$ \\
\hline $\begin{array}{l}\text { Replacing individual } \\
\text { boilers for more } \\
\text { efficient }\end{array}$ & $\$ 4$ bn. & $\$ 1,7$ bn. $\mathrm{m}^{3}$ & $425 \mathrm{~m} \cdot \mathrm{m}^{3}$ \\
\hline Total & $\$ 49$ bn. & $\$ 8,7$ bn. $\mathrm{m}^{3}$ & \\
\hline
\end{tabular}

For the financial support of the population to implement energy efficiency projects, in the form of a refund of a part of the loans or the cost of projects, the amount accumulated under the current programs of funds is about 200 million euros (Figure 7), which is less than $1 \%$ of the investment requirement (provided that the budgets of some programs are used to reimburse the cost of the project). These programs are mainly aimed at supporting the thermal modernization of individual energy efficiency projects but significant savings can only be achieved through complex renovation projects that will ensure the efficient use of energy in consumption.

$\$ 200$ million available financing of
energy efficiency projects

Fig. 7: Available programs of financial support of the population and municipalities in implementation of energy efficiency projects [36]

Estimation of the potential for energy efficiency management of buildings should include two main stages.

The first stage involves evaluation of the energy consumption of the country as a whole. The algorithm of this methodological approach is presented in detail in [37]. The optimal energy consumption per square meter of living space is calculated based on the 
estimation of energy consumption in Ukraine. It is established that the estimated value of the optimal energy consumption level is $37.9 \%$ lower than the actual one. And the indicator of optimal energy consumption per capita is $16.5 \%$ lower than real consumption. Consequently, the existing housing stock has a significant potential for energy savings. The results obtained are important in determining the extent of technical modernization of buildings and the formation of a technical component of energy efficiency management of buildings.

The second stage involves evaluation of the potential of the organizational component of the energy efficiency of the residential sector in a regional context. This makes it possible to carry out a comparative evaluation of the effectiveness of such management and use of energy saving potential in the domestic sector in the regions of Ukraine (including Donetsk and Luhansk regions) in 2016, to rank regions according to the integral rating point.

Under this approach, the organizational component of the energy efficiency management can be estimated by calculating the energy efficiency indicator of the residential sector (energy consumption per square meter of area). This estimate indicator, allows monitoring the trends in household energy consumption. However, the reliability of the results will depend on factors such as regional differentiation of accounting equipment; change in energy prices and tariff policy; income level of the population; structural changes in the residential sector (growth or decrease) of the region, etc. For example, residents of buildings equipped with heat energy meters are more interested in measures to improve their own energy efficiency.

Regional differentiation of this indicator will testify to the effectiveness of energy efficiency management of buildings in Ukraine on a regional basis. In this study, based on the available statistical data of the State Statistics Service of Ukraine [38], the integral rating point of the regions was calculated for their energy saving potential.

Regional comparisons of energy conservation potential are carried out according to seven indicators: the total area of the housing stock (ths. $\mathrm{m}^{2}$ ); the number of available population by region (thousand persons); volume of developed (used) capital investments for electricity, gas, steam and air-conditioned air supply (ths. $\mathrm{UAH}$ ); available income of the population in the regions of Ukraine (UAH million); the share of dwelling houses equipped with multi-apartment thermal energy meters in the total number of multi-apartment buildings to be equipped (percentages); losses of heat energy in heat grids of heat systems (Gcal); electricity losses in power grids of power systems (thousand $\mathrm{kWh}$ ).

The algorithm for estimating the energy saving potential is carried out in three stages.

The first stage of the rating assessment of the energy saving potential is the calculation by summing up the relative deviations of the indicators that characterize the relevant activity of the subjects of the economy of the region to the best values of these indicators of other regions by the formula:

$S_{j}=\sum_{i=1}^{n}\left(\frac{B_{i j}-B_{\min }}{B_{\max }-B_{\min }}\right)+\left(\frac{B_{\max }-B_{i j}}{B_{\max }-B_{\min }}\right)$,

where $S_{j}$ - rating assessment of the energy saving potential of the jth region for each of the indicators;

$B_{i j}-$ the value of the $\mathrm{i}$-th indicator for the $\mathrm{j}$-th region, $1 \leq \mathrm{i} \leq \mathrm{n}$;

$B_{\max }, B_{\min }-$ maximum and minimum values.

The first part of the formula is used to evaluate the indicators of stimulants, the growth of which has a positive value, the second part - to assess the indicators of disinfectants, the growth of which has a negative effect.

The second stage. Determination of the average arithmetic value of the sum of rating evaluations of the energy saving potential of the object of evaluation for each of the indicators by the formula:

$S_{\text {cep }}=\frac{S_{j}}{n}$, where $S_{\text {cep }}$ - the average arithmetic value of the sum of rating evaluations of the energy saving potential of the region upon $n$ indicators:

$n$ - the number of indicators for which the calculation is performed. Third stage. Determination of the integral rating point of the energy saving potential of the region by the formula:

$S_{r j}=\sum\left(S_{c e p} \cdot q_{n}\right)$

where $S_{r j}$ - integral rating point for the energy saving potential of the $\mathrm{j}$-th region;

$q_{n}-$ the weight of the n-th group of indicators.

The region with the highest value $S_{r j}$ has the greatest potential for energy saving.

As a result of the calculations of the integrated estimation of the energy saving potential, the appropriate ranking of Ukrainian regions and their grouping was made (Figure 8). The Dnipropetrovsk, Donetsk, Kyiv and Lviv regions of Ukraine demonstrate the greatest potential for energy saving.

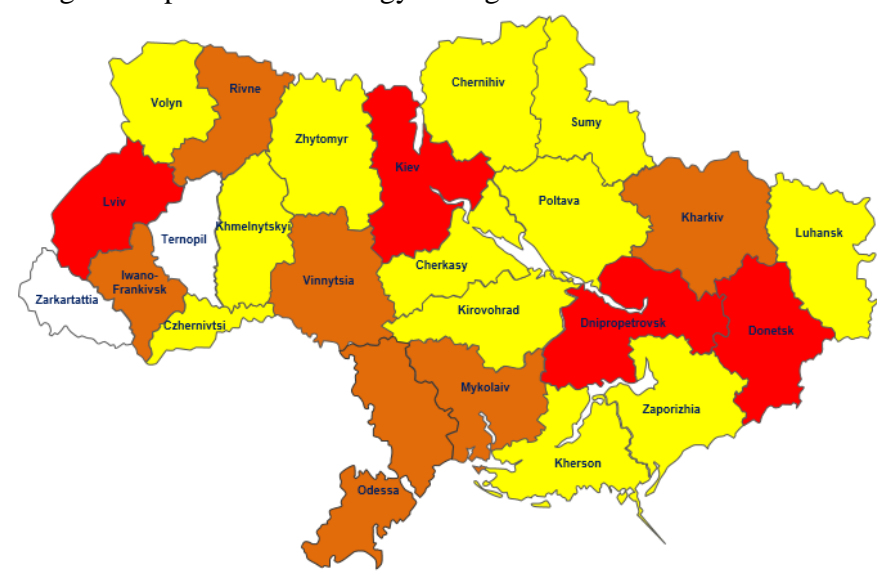

Fig.8: Results of ranking of energy saving potential in the domestic sector by regions of Ukraine, 2016

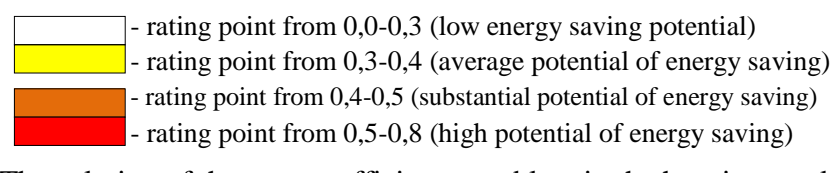

The solution of the energy efficiency problem in the housing stock is a significant reserve for the growth of the economic potential of this area, since the reconstruction and overhaul (thermomodernization) of the housing stock will increase the business activity of enterprises and organizations in the construction industry, will improve the living conditions of the population, will help increase employment as a result of the development of infrastructure in this area (energy audit, energy service companies), will reduce the dependence on exhausted resources.

\section{Conclusion}

The obtained results of the evaluation of the potential of energy efficiency management of buildings allow to evaluate not only the effectiveness of the actions of all branches of power in implementing energy-efficient technologies, but also to identify clearly the feasibility of implementing policy instruments in support of the implementation of sustainable construction practices based on the principles of sustainable development and requires balance of all sustainability factors - economic, energy, environmental and social. Despite some positive energy efficiency changes in Ukraine as a whole, the level of efficiency of the regions of the country varies in different ways, which requires taking into account a certain regional specificity and, accordingly, setting up regions with adequate implementation tasks that take into account both national goals and regional specifics at the same time. At the same time, it should be noted that, in spite of this, Ukraine has not yet defined the criterial basis for assessing energy efficiency, methods for measuring and comparing them (to date, the possibility of an ade- 
quate comparison of different countries and regions of the world according to the level of energy efficiency, taking into account climatic, territorial, infrastructural and other features). In this case, the GDP energy intensity, taking into account purchasing power parity (PPP), is the only indicator, relatively universal and comparable for international and regional comparisons of the energy efficiency.

The experience of the developed countries and Ukraine's own experience point out to the need for state regulation of energy saving processes and conducting a focused state policy. Only the state, through a balanced, legislative, flexible pricing, tariff and tax policy, can ensure the efficiency of the financial mechanism of energy conservation.

Encouraging the population to implement energy saving technologies requires an integrated approach, in which, along with the creation of legislative norms, it is necessary to take into account the economic interests of homeowners and investors. The understanding of this fundamental moment has come in all developed countries of the world.

In recent years, a significant number of state standards have been adopted in Ukraine in various areas, such as energy saving, norm setting of expenditure and losses, energy labeling, energy audits, energy management, secondary energy resources, etc. In 2017, a key document was adopted on improving the management of energy efficiency in housing and communal services, the Law of Ukraine "On the energy efficiency of buildings" [27], the main purpose of which is to create conditions for rational consumption of energy resources. Therefore, improving the organizational and technical potential of providing energy-efficient functioning of the housing and communal services of Ukraine and introducing effective mechanisms for its modernization on the basis of the sustainable building concept should ensure an increase the efficiency of energy efficiency management of buildings.

\section{References}

[1] Im J, Seo Y, Cetin KS \& Singh J (2017), Energy efficiency in U.S residential rental housing: Adoption rates and impact on rent. Journal of Applied Energy 205, 1021-1033. https://doi.org/10.1016/j.apenergy.2017.08.047

[2] Chegut A, Eichholtz P \& Holtermans R (2016), Energy efficiency and economic value in affordable housing. Journal of Energy Policy 97, 39-49. https://doi.org/10.1016/j.enpol.2016.06.043

[3] Triana MA, Lamberts R \& Sassi P (2018), Should we consider climate change for Brazilian social housing? Assessment of energy efficiency adaptation measures. Journal of Energy and Buildings 158, 1379-1392. https://doi.org/10.1016/j.enbuild.2017.11.003

[4] Medrano-Gomez LE \& Izquierdo AE (2017), Social housing retrofit: Improving energy efficiency and thermal comfort for the housing stock recovery in Mexico. Journal of Energy Procedia 121, 4148. https://doi.org/10.1016/j.egypro.2017.08.006

[5] Romanach L, Leviston Z, Jeanneret T \& Gardner J (2017), Lowcarbon homes, thermal comfort and household practices: Uplifting the energy-efficiency discourse. Journal of Energy Procedia 121, 238-245. https://doi.org/10.1016/j.egypro.2017.08.023

[6] Miller W, Liu LA, Amin Z \& Gray M (2018), Involving occupant is net-zero-energy solar housing retrofits: An Australian subtropical case study. Journal of Solar Energy 159, 390-404. https://doi.org/10.1016/j.solener.2017.10.008

[7] Wells L, Rismanchi B \& Aye L (2018), A review of Net Zero Energy Buildings with reflections on the Australian context. Journal of Energy and Buildings 158, 616-628. https://doi.org/10.1016/j.enbuild.2017.10.055

[8] Sanchez-Guevara Sanchez C, Neila Gonzalez FJ \& Hernandez Aja A (2018), Energy poverty methodology based on minima thermal habitability conditions for low income housing in Spain Journal of Energy and Buildings 169 https://doi.org/10.1016/j.enbuild.2018.03.038

[9] De Ayala A, Galarraga I \& Spadaro JV (2016), The price of energy efficiency in the Spanish housing market. Journal of Energy Policy 94, 16-24. https://doi.org/10.1016/j.enpol.2016.03.032

[10] McCade A, Pojani D \& van Groenou AB (2018), The application of renewable energy to social housing: A systematic review. Journal of Energy Policy 114

https://doi.org/10.1016/j.enpol.2017.12.031

[11] Femenias P, Mjornell K \& Thuvander L (2018), Rethinking deep renovation: The perspective of rental housing in Sweden. Journal of Cleaner Production. https://doi.org/10.1016/j.jclepro.2017.12.282

[12] Filippidou F, Nieboer N \& Visscher H (2017), Are we moving fast enough? The energy renovation rate of the Dutch non-profit housing using the national energy labelling database. Journal of Energy Policy 109, 488-498. https://doi.org/10.1016/j.enpol.2017.07.025

[13] Estiri H (2015), The indirect role of households in shaping US residential energy demand patterns. Journal of Energy Policy 86, 585594. https://doi.org/10.1016/j.enpol.2015.08.008

[14] Zuo J \& Zhao Z-Y (2014), Green building research - current status and future agenda: A review. Journal of Renewable and Sustaina$\begin{array}{llll}\text { ble Energy } & \text { Reviews } & 30, & 271-281 .\end{array}$ https://doi.org/10.1016/j.rser.2013.10.021

[15] Shaikh PH, Nor NBM, Sahito AA, Nallagownden P, Elamvazuthi I \& Shaikh MS (2017), Building energy for sustainable development in Malaysia: A review. Journal of Renewable and Sustainable Energy Reviews 75, 1392-1403. https://doi.org/10.1016/j.rser.2016.11.128

[16] Hakkinen T, Rekola M, Ala-Juusela M \& Ruuska A (2016), Role of Municipal Steering in Sustainable Building and Refurbishment. Journal of Energy Procedia 96, 650-661. https://doi.org/10.1016/j.egypro.2016.09.123

[17] Gillingham K \& Palmer K (2014), Bridging the energy efficiency gap: Policy insights from economic theory and empirical evidence. Journal of Review of Environmental Economics and Policy, 8(1), 18-38. https://doi.org/10.1093/reep/ret021

[18] Smith G. \& Parmenter K. (2015), Energy Management Principles (2nded.). USA: Elsevier.

[19] Sioshansi FP. (2016), Future of Utilities - Utilities of the Future: How Technological Innovations in Distributed Energy Resources Will Reshape the Electric Power Sector (1st ed.). USA: Elsevier.

[20] Kayakutu G. \& Mercier-Laurent E. (2016), Intelligence in Energy (1st ed.). USA: Elsevier.

[21] Kapustian VO \& Chepeliev M.H. (2014), Ekonomikomatematychne modeliuvannia naslidkiv enerhetychnykh subsydii: pryntsyp adekvatnosti. Ekonomichnyi analiz: zb. nauk. prats, 1, 86100.

[22] Sukhonos MK, Molodchenko TH \& Prasol VM (2014), Analiz tekhnichnoho stanu zhytlovoho fondu Ukrainy ta propozytsii shchodo yoho otsinky. Ekonomichnyi visnyk Donbasu, 1(35), 5155 .

[23] Volkov VP (2013), Problemy enerhozberezhennia v zhytlovomu fondi. Ekonomichnyi visnyk universytetu, 20(1), 83-90.

[24] Onyshchenko V \& Sivitska S (2014), Alternative energy developing investment support in terms of energy dependence. Economic Annals-XXI, 9-10, pp. 34-37.

[25] Enerdata. Global Energy Statistical Yearbook 2017, available online: https://yearbook.enerdata.net/total-energy/world-energyintensity-gdp-data.html, last visit: 3.04.2018

[26] Site of International Energy Agency. World Energy Investment 2017, available online: http://www.iea.org/Textbase/npsum/WEI2017SUM.pdf, last visit: 04.04 .2018

[27] Sait Verkhovnoi Rady Ukrainy. Zakonadavstvo Ukrainy, available online: http://zakon3.rada.gov.ua/laws/show/2118-19, last visit: 21.03.2018

[28] Iwaro J \& Mwasha A (2013), The impact of sustainable building envelope design on building sustainability using Integrated Performance Model. International Journal of Sustainable Built Environment 2, 153-171. https://doi.org/10.1016/j.ijsbe.2014.03.002

[29] Dosvid krain Yevrosoiuzu z pidvyshchennia enerhoefektyvnosti, enerhoaudytu ta enerhomenedzhmentu $\mathrm{z}$ enerhooshchadnosti $\mathrm{v}$ ekonomitsi krain, available online: https://ua.energy/wpcontent/uploads/2018/01/Pidvyshhennya-energoefektyvnosti-vYES.pdf, last visit: 29.03.2018

[30] Site of the Internet publication «TRYMAI KURS». Kroky, yaki zbilshat enerhoefektyvnist zhytla, available online: http://kurs.if.ua/articles/kroky_yaki_zbilshat_energoefektyvnist_zh ytla_infografika_58600.html, last visit: 04.04.2018

[31] Site of the Internet publication «ESKO. Horoda i zdaniia». Enerhosberehaiushchie tekhnolohii pri stroitelctve zdanii: passivnyi dom, available online: http://www.journal.esco.co.ua/cities/2013_3/art119.html, last visit 09.04 .2018

[32] Site of the Internet publication «EKO system». Pasyvnyi Dim, available online: http://www.ekosystem.lviv.ua/p-energyhome, last visit: 09.04.2018 
[33] Site of the Internet publication «BudEkspert». «Pasyvnyi budunok» - innovatsiina tekhnolohiia $\mathrm{v}$ enerhoefektyvnomu budivnytstvi, available online: http://www.budexpert.ua/ru/content/detail/659, last visit: 09.04.2018

[34] Site of the Internet publication «EKSPERT ONLINE». Zhyzn po zelenomu kodu, available online: http://expert.ru/expert/2012/13/zhizn-po-zelenomu-kodu, last visit: 10.04 .2018

[35] Site of the Internet publication «NoSEP». Reitynh enerhoefektuvnosti teplozabezpechennia 2016, available online: http://newsep.com.ua/new/1030, last visit: 07.04.2018

[36] Site of the Internet publication «Zhytlo». Mekhanizmy finansyvannia zakhodiv enerhoefektyvnosti $\mathrm{v}$ Ukraini, available online: https://zhytlo.in.ua/ua/napryamok/energozberezhennya/mehanzmi_f nansuvannya_zahodv_energoefektivnost_v_ukran.html, last visit: 10.04.2018

[37] Komelina OV. \& Shcherbinina SA. (2018), Methodology of estimation of energy reserves and energy efficiency of the housing fund of Ukraine, Marketing and Management of innovations, 1, 382-390. DOI:10.21272/mmi.2018.1-30

[38] Site of state statistics service of Ukraine, available online: http://www.ukrstat.gov.ua/, last visit: 03.04.2018 